\title{
Business Valuation of Nike, Incorporated
}

\author{
Elena Miroshina (Silantieva) ${ }^{1}$, Egor Romanov ${ }^{2}$
}

${ }^{1}$ Department of International Economy and World Finance, Financial University, Moscow, Russia; EASila@yandex.ru 2International Finance Faculty, Financial University, Moscow, Russia; egor-romanov98@mail.ru

Abstract

In this article we focused on the ability to analyze the market and to carry out complex assessment of the company, that is one of the most paramount tasks before financiers. We tried to understand if Nike, Inc. company is overvalued or not. In this work we will consider the analysis of Nike, Inc. by means of Discrete Cash Flow (DCF) as a method and the analysis of financial statements.

Keywords: business valuation; DCF; Financial Analysis; Nike, Inc.

JEL classification: D22, F23, G32

$\mathrm{N}$ IKE, incorporated on September 8, 1969, is engaged in the design, development, marketing and selling of athletic footwear, apparel, equipment, accessories and services. The Company's operating segments include North America, Western Europe, Central \& Eastern Europe, Greater China, Japan and Emerging Markets. The Company's portfolio brands include the NIKE Brand, Jordan Brand, Hurley and Converse. The Company sells its products to retail accounts, through its retail stores and Internet Websites, and through a mix of independent distributors and licensees across the world. The Company's products are manufactured by independent contractors.

\section{Financial Analysis}

\section{Revenues}

For the first time in a while, NIKE reported flat revenue growth in its latest quarterly report. The company is facing strong competition from Adidas and Under Armour. Both competitors are going after sportswear and women segments where fashion is an important element.

Declining sales in North America along with currency headwinds explain recent revenue deception. The company is going through a transformation where it will increase direct-to-customer sales through owned stores and online sales. The idea is to get closer to clients, identify their needs and change of taste to make modification accordingly. I think this is a smart idea. Customers are shifting their buying patterns and online sales will help gather additional data to improve the company's product. Nike also started a pilot project with Amazon. As opposed to classic retailers, Nike has nothing to fear from Amazon. It's impossible for them to sell Nike shoes without Nike.

\section{Earnings}

As previously mentioned, strong competition led Nike to cut prices and spend a fortune in marketing to keep its market share. Nike is an icon brand and its marketing budget is unmatched in the industry. The company dominates the basketball industry and is taking a serious foot inside the growing soccer market. Unfortunately, as competition grows, margins are under pressure. We can see that it is slightly weaker than usual:

It is expected that Nike will increase direct sales to improve margins in the future. As the company will learn more about its clients, it should target their needs and improve the amount of sales and profits.

\section{Dividend Growth Perspective}

Nike has increased its dividend for 15 consecutive years. This makes it part of the Dividend Achievers list. The Dividend Achievers Index refers to all public companies that have successfully increased 


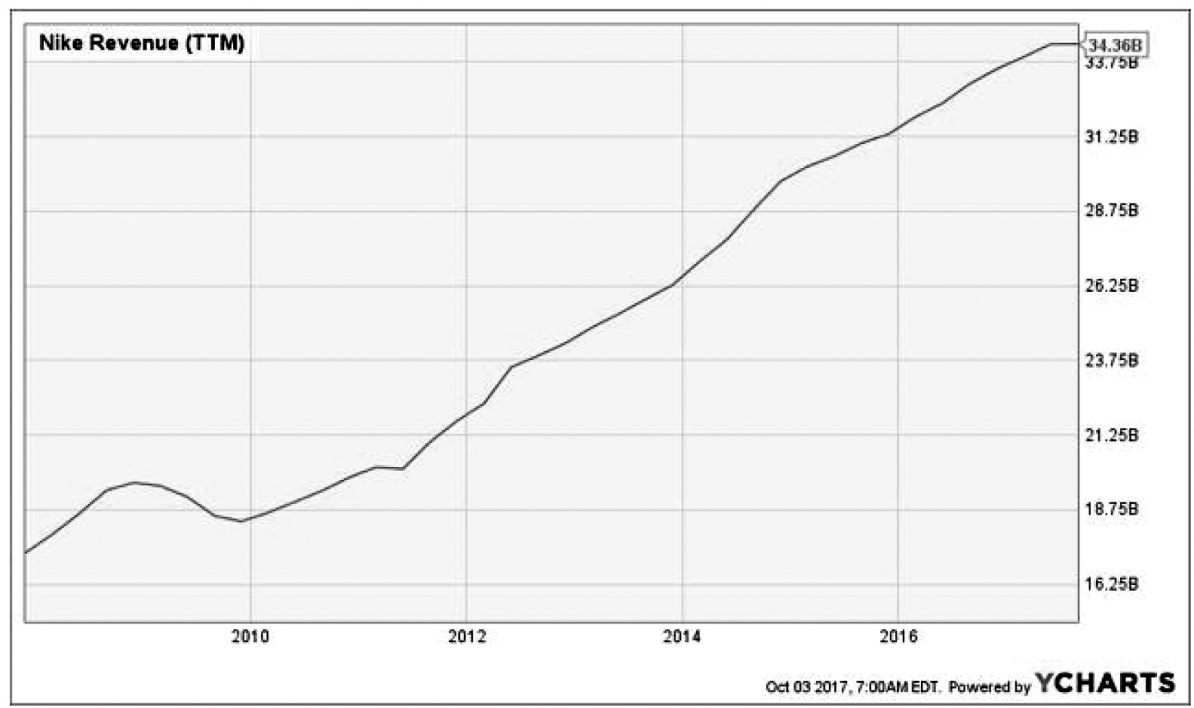

Figure 1. Nike Revenue 2010-2016.

Source: https://ycharts.com/store/nike

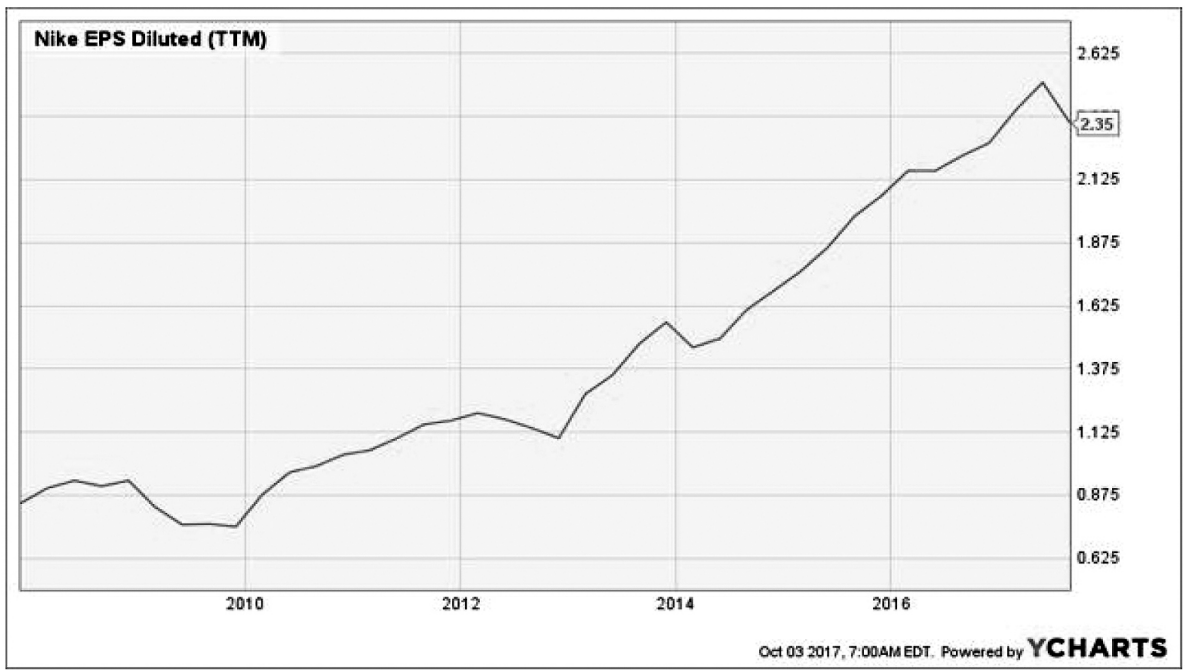

Source: https://ycharts.com/store/nike

Figure 2. Nike earnings (EPS) 2010-2016.

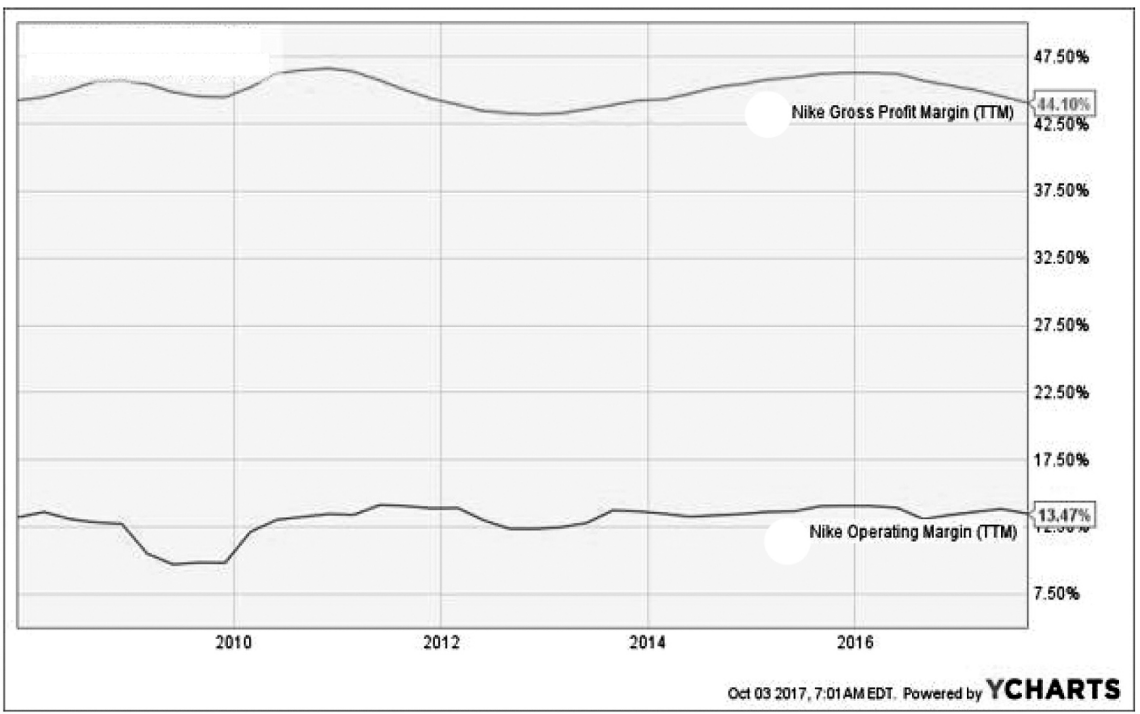

Figure 3. Nike's operating margin 2010-2016.

Source: https://ycharts.com/store/nike 


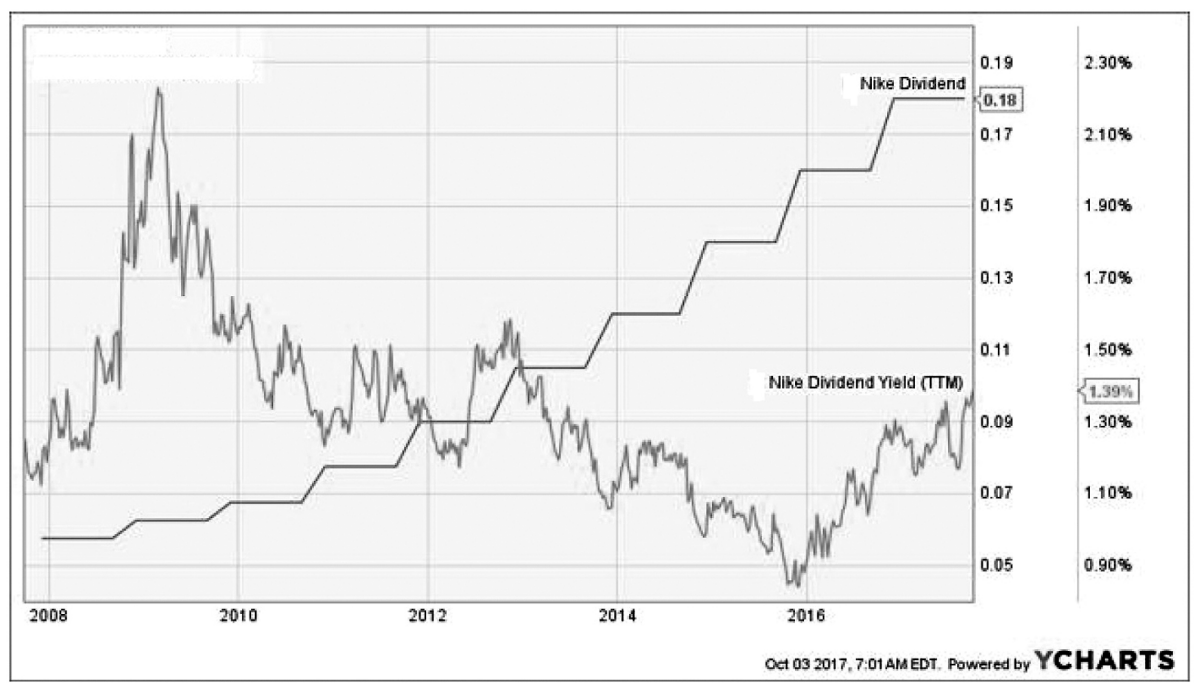

Figure 4. Nike's Dividends 2008-2016.

Source: https://ycharts.com/store/nike

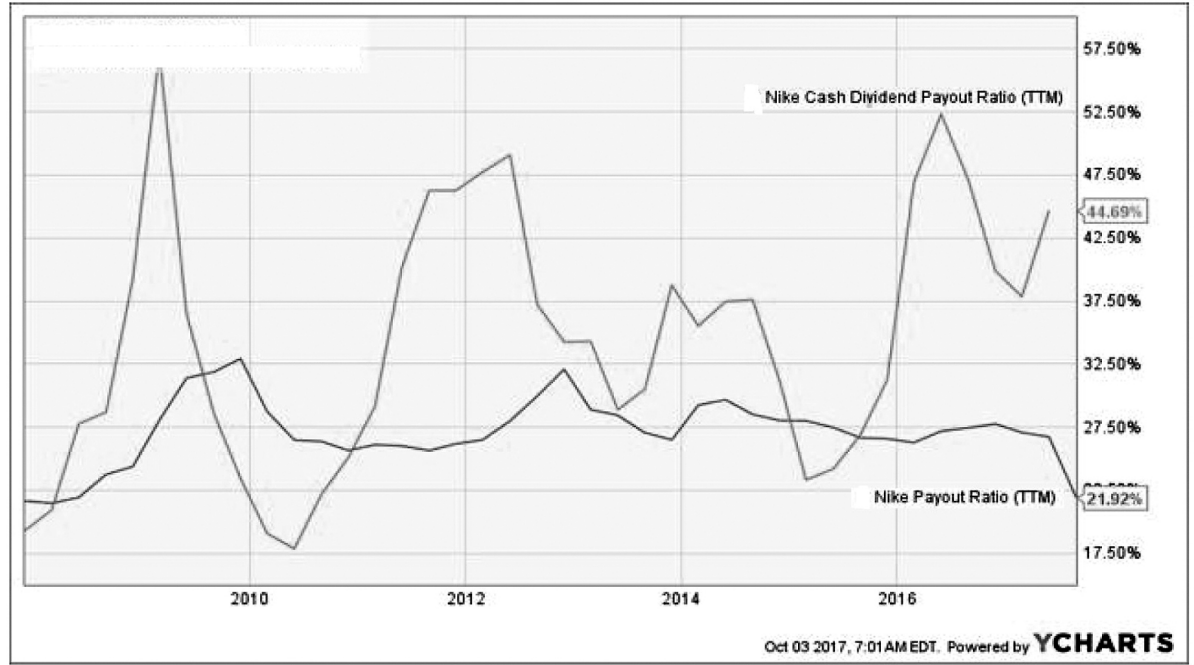

Figure 5. Nike's Payout Ratio (TTM) and Nike's Cash Dividend Payout Ratio 2010-2016.

Source: https://ycharts.com/store/nike

their dividend payments for at least 10 consecutive years. At the time of writing this work, we have found 265 companies that achieved this milestone.

The company usually flies under the radar of many dividend growth investors as its yield has not been a stock highlight for the past seven years. However, the dividend payment doubled over the past five years and the company is in line to announce its $16^{\text {th }}$ consecutive dividend raise later in 2017.

The good thing about sports apparel is that the more client uses them, the more he/she buys. It's virtually impossible to keep the same running shoes for more than a year if somebody runs 3-4 times a week. This generates repetitive sales leading to continuous cash flow generation.

While management is on a roll to buy back shares and increase significantly its distribution, both payout and cash payout ratios are well under control. In fact, management has enough room to keep a high single-digit to double digit dividend growth rate for many years to come.

\section{Potential Downsides}

The company is well implemented across the world. While there are still growth vectors coming from China and emerging markets, North American and European markets may continue to go sideways. Nike has been known for its affiliation with many stars in the sport industry. Sponsoring has been a 
proven, but expensive strategy. As competition intensifies, such spending will hurt margins. Overall, there are not any major dark clouds hovering over Nike's head.

\section{Discrete Cash Flow method}

Let's start with the calculation of Weighted Average Cost of Capital (WACC - see https://www.gurufocus.com/term/wacc/NKE/WACC/Nike+Inc):

WACC $=\mathrm{E} /(\mathrm{E}+\mathrm{D}) \times$ Cost of Equity $+\mathrm{D} /(\mathrm{E}+\mathrm{D}) \times$ Cost of Debt $\times(1-$ Tax Rate $)$

1. Weights:

Generally speaking, a company's assets are financed by debt and equity. We need to calculate the weight of equity and the weight of debt.

The market value of equity (E) is also called "Market Cap (M)". As of today, Nike's market capitalization (E) is \$ 98217.390 million.

The market value of debt is typically difficult to calculate, therefore, we use book value of debt (D) to do the calculation. It is simplified by adding the latest two-year average Current Portion of Long-Term Debt and Long-Term Debt \& Capital Lease Obligation together. As of Aug., 2017, Nike's latest two-year average Current Portion of Long-Term Debt was \$ 2732 million and its latest twoyear average Long-Term Debt \& Capital Lease Obligation was \$ 2732 million. The total Book Value of Debt (D) is \$2920 million.

a) weight of equity $=E /(E+D)=98217.390 /(98217.390+2920)=0.9711$

b) weight of debt $=\mathrm{D} /(\mathrm{E}+\mathrm{D})=2920 /(98217.390\}+2920)=0.0289$

2. Cost of Equity:

We use Capital Asset Pricing Model (CAPM) to calculate the required rate of return. The formula is: Cost of Equity $=$ Risk-Free Rate of Return + Beta of Asset $\times$ (Expected Return of the Market - RiskFree Rate of Return)

a) We use 10-Year Treasury Constant Maturity Rate as the risk-free rate. It is updated daily. The current risk-free rate is $2.37000000 \%$.

b) Beta is the sensitivity of the expected excess asset returns to the expected excess market returns. Nike's beta is 0.51 .

c) (Expected Return of the Market - Risk-Free Rate of Return) is also called market premium. We consider market premium to be $6 \%$.

Cost of Equity $=2.37000000 \%+0.51 \times 6 \%=5.43 \%$

3. Cost of Debt:

We use last fiscal year end Interest Expense divided by the latest two-year average debt to get the simplified cost of debt.

As of May, 2017, Nike's interest expense (positive number) was 59 million. Its total Book Value of Debt (D) is \$ 2920 million.

Cost of Debt $=59 / 2920=2.0205 \%$.

4. Multiply by one minus Average Tax Rate:

We use the latest two-year average tax rate to do the calculation. The latest Two-year Average Tax Rate is $15.945 \%$.

Weighted Average Cost of Capital (WACC) for today is calculated as:

WACC $=\mathrm{E} /(\mathrm{E}+\mathrm{D}) \times$ Cost of Equity $+\mathrm{D} /(\mathrm{E}+\mathrm{D}) \times$ Cost of Debt $\times(1-$ Tax Rate $)$

WACC $=0.9707 \times 5.43 \%+0.0293 \times 2.0205 \% \times(1-15.945 \%)=5.34 \%$

After calculating WACC we should find out more information about the Free Cash Flow (FCF). This information is available in Bloomberg terminal.

Free Cash Flow for the future 5 year period (in millions) (Nike Inc., n.d.):
1) FCF 2017-2535
2) FCF 2018-3194
3) FCF 2019-3550
4) FCF 2020-3970
5) FCF 2021-4046. 
Now we need discount all the future FCF to current day with the help of WACC.

$\left[\mathrm{FCF}_{17} /(1+\mathrm{WACC})\right]+\left[\mathrm{FCF}_{18} /\left(1+\mathrm{WACC}^{2}\right]+\left(\mathrm{FCF}_{10} /\left(1+\mathrm{WACC}^{3}\right]+\left(\mathrm{FCF}_{20} /\left(1+\mathrm{WACC}^{4}\right]+\left(\mathrm{FCF}_{21} /(1+\right.\right.\right.\right.$ WACC $\left.)^{5}\right]+\mathrm{TV} /(1+\mathrm{WACC})^{6}$ that is

2535/1.0534 + 3194/1.109 + 3550/1.168 + 3970/1.229 + 4046/1.295 + TV/1.361 = Market Capitalization.

We can calculate Terminal Value (TV) in two ways:

TV by exit multiple approach

TV=EBITDA ${ }_{2022} \times{\mathrm{EV} / \mathrm{EBITDA}_{2022}}+$ Cash - DebtI dare to forecast that EV/EBITDA in 2022 will be 12.696 due to historical data and Bloomberg terminal.

So, $\mathrm{TV}=8444 \times 12.696+5519-3814=108910$ million.

Market Capitalization:

2535/1.0534 + 3194/1.109 + 3550/1.168 + 3970/1.229 + 4046/1.295 + 108910/1.361= 94765 million.

\section{Gordon Growth Model}

$2.3 \%$ - Long term growth rate

$\mathrm{TV}=\left(\mathrm{FCF}_{2021} \times 1.023\right) /(\mathrm{WACC}-0.023)$

$\mathrm{TV}=(4046 \times 1.023) /(0.0534-0.023)=4139 / 0.034=136151$

Market Capitalization:

2535/1.0534 + 3194/1.109 + 3550/1.168 + 3970/1.229 + 4046/1.295 + 136151/1.361= 114718 million.

The financial analysis of the company has demonstrated that Nike, Inc. performs really well over the last years in the market of sport apparel and how potentially beneficial it can be in the near future. Comparative approach has shown that the market value of Nike's shares are overvalued, but it is connected with many different factors that take place in the sphere of sport apparel. However, basing on the DCF analysis the company is undervalued to its fair value, so that its shares has a potential to grow. That is why we dare to give a recommendation to buy Nike's shares in Q1 2018.

\section{References}

Nike Revenue. Retrieved October 03, 2017, from https://ycharts.com/store/nike Nike's EPS. Retrieved October 03, 2017, from https://ycharts.com/store/nike Nike’s operating margin. Retrieved October 03, 2017, from https://ycharts.com/store/nike Nike’s Dividends. Retrieved October 03, 2017, from https://ycharts.com/store/nike Nike's Payout Ratio. Retrieved October 03, 2017, from https://ycharts.com/store/nike WACC. Retrieved November 12, 2017, from https://www.gurufocus.com/term/wacc/NKE/WACC/Nike+Inc. Nike Inc. Retrieved November 12, 2017, from http://search.morningstar.com/sitesearch/search.aspx?s=o\&q=Nike Gordon Growth Model. Retrieved December 24, 2017, from https://www.investopedia.com/terms/g/gordongrowthmodel.asp

\section{Оценка бизнеса корпорации Nike}

\section{Елена Мирошина (Силантьева) ${ }^{1}$, Егор Романов²}

В этой статье мы сосредоточили внимание на способности анализировать рынок и проводить комплексную оценку компании, что является одной из наиболее важных задач перед финансистами. Мы попытались понять, переоценена ли компания Nike, Incorporated или нет. В работе мы провели анализ результатов деятельности Nike, Inc. посредством дискретного денежного потока (DCF) в качестве метода и анализа финансовой отчетности.

Ключевые слова: инвестиционная оценка; DCF; анализ финансовой отчетности; корпорация Найк JEL classification: D22, F23, G32

${ }^{1}$ доцент, Департамент мировой экономики и мировых финансов, Финансовый университет, Москва; EASila@yandex.ru

2 Международный финансовый факультет, Финансовый университет, Москва; egor-romanov98@mail.ru 